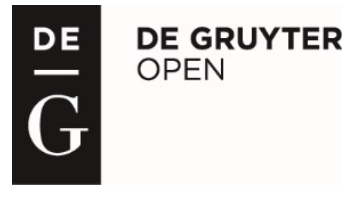

LEGE ARTIS

Language yesterday, today, tomorrow

Vol. II. No 12017

\title{
ECHO QUESTIONS AS A MEANS OF BUILDING COHERENCE IN CONVERSATIONAL DISCOURSE
}

\section{Natalia Strelchenko}

Strelchenko, N. Echo questions as a means of building coherence in conversational discourse // Lege artis. Language yesterday, today, tomorrow. The Journal of University of SS Cyril and Methodius in Trnava. Warsaw: De Gruyter Open, 2017, vol. II(1), June 2017. p. 336-378. DOI: 10.1515/ lart-2017-0009

\begin{abstract}
The study focuses on the cognitive-communicative characteristics of echo questions in English conversational discourse. Drawing on van Dijk's sociocognitive (mental model) theory and cognitive discourse analysis, the paper suggests viewing echo questions as a means of building/updating a mental context model of a communicative situation. As discourse comprehension presupposes building its coherent mental model, echo questions resolving misunderstanding are regarded as an instrument for increasing coherence in conversational discourse. Based on the mental model theory, the study offers a typology of misunderstandings corrected by echo questions.
\end{abstract}

Key words: echo question, mental model, discourse comprehension, coherence, misunderstanding, knowledge, conversational discourse.

\section{Introduction}

This paper further develops an approach to studying the cognitive-communicative characteristics of echo questions drawing on van Dijk's $(2008 ; 2014)$ sociocognitive theory of discourse analysis (Стрельченко 2016). In the literature, several definitions of the term "echo question" can be found (Radford 2009: 383; Leech 2006: 35; Santorini \& Kroch 2007). For instance, Teschner and Evans (2007: 64) define echo questions as questions, which "repeat, directly or in paraphrase all or part of what someone else has just said, either to confirm it or to express surprise or disbelief". For the purposes of our analysis, the following features of echo questions are taken into 
account: connection with the interlocutor's previous and following utterances; expression of rational and/or emotional information; semantic and/or structural relations with the preceding utterance (Стрельченко 2015: 246). We will refer to the communicator producing an echo question as speaker B, while his/her interlocutor, producing the stimulus utterance (McCawley's term (1998: 561)) and reacting to an echo question will be termed speaker A. With this distinction in mind (important for the typology developed in the paper), in the analysis chapter we provide detailed descriptions of communicative situations (including individual speakers' names, etc.) to illustrate the influence of the contextual factors on the use of echo questions.

As van Dijk suggests, discourse production and comprehension are regulated by a mental context model of the communicative situation (van Dijk 2008: 16). On the other hand, understanding a discourse presupposes building its coherent mental model (van Dijk 2012: 589), which may represent both the speaker's personal experience and discourse (such as news or a story) (van Dijk 2012: 588-589). As the plot of a story evolves, the reader updates their current mental model (Zwaan \& Madden 2004: 283). Analogously, the interlocutor's contribution in conversational discourse may be viewed as influencing the existing mental model of the discourse because "many of the processes of comprehension are assumed to be common to listening and reading" (Garnham 2005: 241).

The structure of a mental model is at least partially isomorphic with the sentence meaning, e.g., in the case of reading, the protagonist in a story corresponds to the agent on the syntactic level (van Dijk 2014: 53), which can be grounds for regarding echo questions, used for the elaboration of the interlocutor's message, as a means of updating the speaker's mental model of the communicative situation. When misunderstandings arise, echo questions are employed to repair communicative failures by asking for clarification (the distinction between elaboration and clarification is based on Schiffrin (2006: 276)). 
Apart from the explicitly stated verbal information, mental models contain knowledge and beliefs shared by members of a community, which are used to draw inferences and make mutual understanding possible (Zwaan \& Radvansky 1998: 163). Discourse comprehension involves reconstructing a mental model of the interlocutor's discourse (van Dijk 2012: 588-589). Thus, echo questions, used as a reaction to something just said, may be taken to indicate how well the previous utterance has been understood and repair communicative failures when needed. The aim of the study is to elucidate the role of echo questions as a means of increasing coherence in conversational discourse by resolving misunderstanding and offer a typology of the latter.

As both echo questions and mental model theory have been researched in a number of publications, a brief commentary on the novelty of the paper is in order. Echo questions as a part of the English grammatical system have been presented by Carter \& McCarthy (2006: 199), Huddleston (1984: 376-377), Quirk et al. (1985: 835-837), Radford (2009: 20-21), Teschner \& Evans (2007: 64). Sobin (1989; 2009) analyzed their syntactic features from the viewpoint of generative grammar. Reis (2012: 1), focusing on echo wh-questions in German, argues that "the pragmatic properties of echo questions are derived from their formal properties, notably, their focusing properties, in a non-ad hoc way". In contrast, this study is functionally oriented with its focus on the cognitivecommunicative aspect of echo questions.

In psycholinguistics and cognitive psychology, mental models (their structure, components, and the processes of building/updating) are studied with reference to reading (e.g., Zwaan \& Madden 2004; Zwaan \& Radvansky 1998; Zwaan \& Rapp 2006) rather than conversational discourse. While originally devised to pinpoint the processes of discourse production and comprehension, van Dijk's mental model theory (van Dijk \& Kintsch 1983) has been employed to study news discourse and ideological issues (van Dijk 2008; 2014; 2015). However, to the best of our knowledge, this is the 
first attempt at its application to the analysis of conversational discourse and to the functioning of echo questions in particular.

\section{Material and methods}

The methods used are determined by the aim of the study, its theoretical assumptions and the language material, and are complex in character. Cognitive discourse analysis (after van Dijk (2000)) is used to establish the components of the mental context model of the communicative situation, which cause misunderstanding of the interlocutor's utterance, resolved by an echo question. The research also takes into account basic tenets of van Dijk's sociocognitive theory of discourse studies, psycholinguistics (levels of message perception/comprehension, mental model theory), and pragmatics (speech act theory, cooperation).

Conversational discourse fragments featuring echo questions have been selected from British and American films of the 20th and 21st centuries. The choice of films as appropriate material for studying conversational phenomena (i.e., echo questions common in conversational discourse (Carter \& McCarthy 2006: 199)) is based on the assumption that "the use of television dialogue as a surrogate for natural conversation for the analysis of certain linguistic features seems perfectly appropriate" (Quaglio 2009: 148-149). Films enable us to take audio-visual information into account as the communicative context plays a crucial role in studying echo questions. In contrast, natural interaction in institutional settings (e.g., in interviews, patient-doctor dialogues, etc.) does not allow the researcher access to the communicators' context models, the components of which are verbalized by echo questions, as he/she performs the role of an overhearer, not the addressee of the discourse (as is the case with films) (Dynel 2014: 29).

Bearing in mind that "film scripts generally fall short of capturing the varied and subtle characteristics of spontaneous dialogue" (Taylor 2004: 71), we formed the corpus of 
discourse fragments on the basis of websites with open subtitles, transcripts of dialogue, and own transcription, taking into account the actual language used in the characters' interactions, which often differs from the script in terms of wording and grammatical accuracy. If necessary, we supplied information on the context and nonverbal communication, drawing on the characters' (prior) conversations and actions on screen. It should be noted that the discourse fragments transcribed contain numerous examples of hesitations, false starts, syntactic anomalies, and discourse markers (e.g., well, you know, oh), which are considered to be characteristic of unscripted conversation (Leech \& Short 2007: 129-131).

\section{Cognitive-communicative characteristics of echo questions from the perspective of mental model theory}

Cognitive-communicative characteristics of echo questions pertain to their role in discourse production and comprehension, which are controlled by mental models ("subjective representations of events or situations in which a person participates at a certain moment of time, at a certain place, with other participants (with variable identities and social roles), engaged in a specific action and with specific goals" (van Dijk 2012: 588)). Van Dijk distinguishes between a semantic situation model, which represents a situation or events referred to in a discourse, and a dynamic pragmatic context model of the communicative situation in which the interlocutors are engaged (van Dijk 2012: 588-589). The term "context model" refers to "a specific mental model, or subjective interpretation, of participants of the relevant properties of the (social, interactional or communicative) situation in which they participate" (van Dijk 2008: 24) "in episodic (autobiographical) memory" and which "ongoingly controls the processes of discourse production and comprehension" (van Dijk 2008: 16).

Context models ensure that the discourse is appropriate for the communicative situation and contain information about the communicators with respect to their communicative roles (speaker, recipient, author, etc.), social roles or identities 
(teacher, journalist), social categories (gender, class, age, etc.), relationships (friend, enemy), "the current goals, intentions, and knowledge state of the participants at each moment of interaction" (van Dijk 2012: 589). Context models may also characterize a communicative situation with respect to time, location, circumstances, events (participants and their roles, action/discourse, cognition: aims, goals, knowledge, opinions, emotions) (van Dijk 1999: 131). According to van Dijk (2008: 19), context models control discourse indirectly, and their influence only becomes explicit in cases of communicative failures.

Our analysis of language material revealed that echo questions in conversational discourse are used to resolve misunderstanding by asking for clarification (discussed in Chapter 3) as well as build/update context models, which influence communicative interaction, and situation models of the past events being discussed.

When a mental context model is built, echo questions are used to elaborate on its components such as the interlocutor's personality, his/her status and role, knowledge, beliefs, expectations, intentions, plans, attitudes, emotions, and the subject being discussed (Стрельченко 2016). For instance, asking the interlocutor if he/she has certain knowledge, the speaker can decide on the need to provide further information: (1) Myrna Harris: My mum said that I'd be an-an accessory before the fact.

Inspector Craddock: Do you know what that means?

Myrna Harris (shakes her head): It sounded horrible ("A murder is announced"). Here and below the titles of used films are given in brackets. Some of them are presented in Table 3 in Notes.

Besides, echo questions may be used to inquire about the necessity of giving some information (Do you really want to know? ("Dumb witness")), its source (How did you know? ("Why didn't they ask Evans?"), How did you hear about it? ("Why didn't they 
ask Evans?")), and reliability of the latter (Is Miss Bunner a reliable witness? ("A murder is announced")).

Aspects of the situation model elaborated by echo questions include the time/period of an action (Was this in the olden days? ("A murder is announced"), On Saturday? Are you sure? ("A murder is announced")), characterization/categorization of a past event (Didn't turn out to be suicide or anything, did it? ("Why didn't they ask Evans?")), place of action (Was that in a place called Marchbolt? ("Why didn't they ask Evans?")) or the speaker's location at a certain time in the past (Where was I? ("Four and twenty blackbirds")), a person performing a certain action (And there's no indication as to who it was? ("A murder is announced")), his/her name, status, characteristics, behaviour (including past conversations), attitudes, wishes, and motives (Стрельченко 2016).

The relationship between context models of communicative situations and situation models of past events may be viewed as inclusion: a situation model, representing a past event experienced by the speaker or the discourse about it, constitutes a component of the context model (namely knowledge). As this paper focuses primarily on the role echo questions play in conversational discourse coherence, mental situation and context models will not be discussed in detail. The components of mental models actualized by echo questions are represented in the figure below (see Fig. 1). 


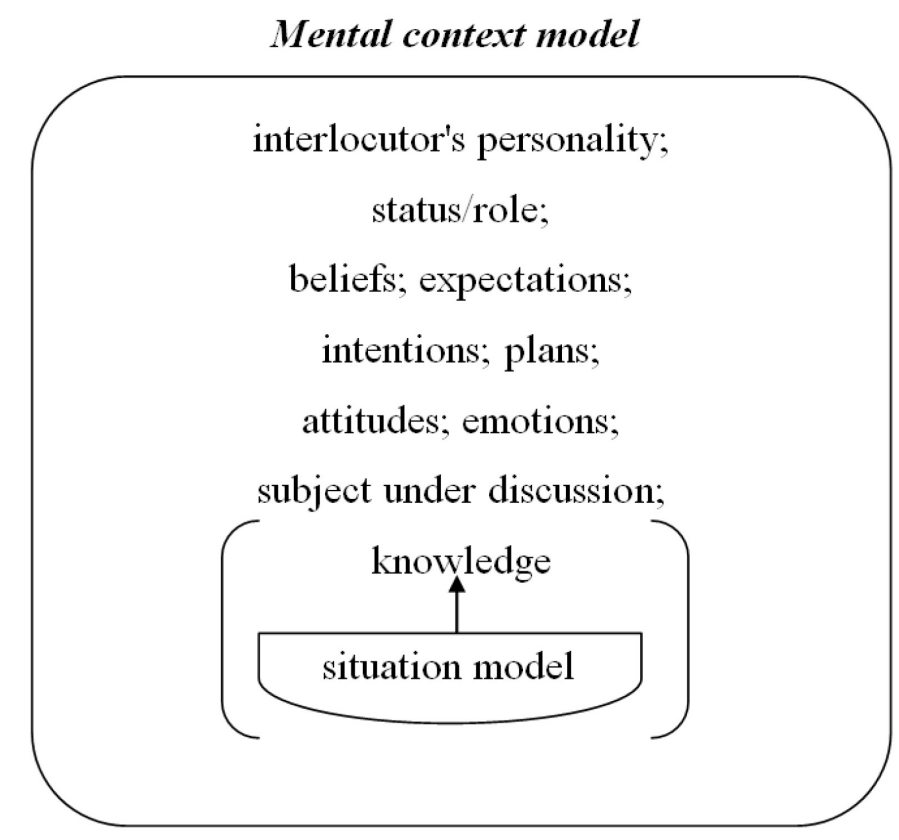

Figure 1. Components of the mental context model inquired about by echo questions

\section{Echo questions increasing coherence and resolving misunderstanding in conversational discourse}

Considering echo questions to be an indication of understanding of the interlocutor's previous utterance is based on the assumption that discourse comprehension presupposes building its coherent mental model (van Dijk 2012: 589). Understanding here is taken to refer both to the situation ("the fragment of the objective reality corresponding to the sentence meaning" (Долинин 1983: 39)) in the past or the communicative interaction (necessary to build the mental situation/context model) and the interlocutor's utterance, which then influence the speaker's next contribution by means of the updated mental context model.

In psycholinguistics, language comprehension is studied on the "lexical, syntactic, and discourse (message) level" (Garnham 2005: 241). Word identification involves using the mental lexicon, which provides information about the spelling, standard pronunciation, part of speech, and meaning of a word (Garnham 2005: 241-242). Word 
identification is followed by their syntactic analysis (parsing): formation of wordgroups and sentences and filling thematic roles (Garnham 2005: 243-245).

Our study of the use of echo questions reveals that word identification problems may be caused by speaker A (unclear pronunciation of the stimulus), speaker B (who cannot perceive/comprehend the interlocutor's utterance due to a hearing impairment or his/her psychological and emotional state), and the environment where communication takes place (e.g., noise). Consider the following communicative situation.

(2) Morse rings the bell.

Mrs. Rawlinson: Who is it?

Morse: Chief Inspector Morse. CID.

Mrs. Rawlinson: Who?

Chief Inspector Morse (louder): Inspector Morse. Oxford CID.

Mrs. Rawlinson: I'II press the buzzer. (Buzzer)

Chief Inspector Morse: Hello. Mrs. Rawlinson?

Mrs. Rawlinson: Yes, I'm afraid I didn't quite catch your name. That silly contraption. Chief Inspector Morse: Morse. Inspector Morse ("Service of all the dead").

Mrs. Rawlinson uses an echo question to ask Chief Inspector Morse to introduce himself again as she could not perceive his previous utterance because of a hearing impairment.

Factors causing lexical problems include situations in which speaker B does not know a word (because of his/her insufficient level of lexical competence or the register of the lexical item) or when speaker A's utterance is ambiguous due to polysemy. Discourse fragments (3)-(6) illustrate the cases mentioned.

(3) Chief Inspector Morse: This is your umbrella, sir? 
Matthew Copley-Barnes: I imagine so.

Chief Inspector Morse: You imagine so? Was Dr Deer's identical?

Matthew Copley-Barnes: Would you expect mine, that is the master's umbrella, to display some differentiating feature from that of a senior fellow's? Perhaps you have some general interest in the taxonomy of umbrellas, Chief Inspector?

Sergeant Lewis: Taxonomy? Sounds like stuffing something. Stuffed umbrellas?

Chief Inspector Morse: No, Lewis, taxonomy is classification. The master was making a joke ("The infernal serpent").

Sergeant Lewis, present during a police interview of an Oxford master conducted by Chief Inspector Morse, uses an echo question to check how well he has understood the word taxonomy, which resembles taxidermist to him. Morse's reaction indicates that the sergeant's assumption about the word meaning has been inaccurate, and he explains what was actually meant.

In the following situation - an exchange between a ringleader (McGinty) and a prospective new member who wants to join the organization - McGinty's echo question is used to establish the meaning of a slang expression used by his future subordinate.

(4) "I was helping Uncle Sam to make dollars. Maybe mine were not as good gold as his, but they looked as well and were cheaper to make. This man Pinto helped me to shove the queer-"

\section{"To do what?"}

"Well, it means to pass the dollars out into circulation. Then he said he would split. Maybe he did split. I didn't wait to see. I just killed him and lighted out for the coal country" (Doyle 1993: 912).

Ambiguity of speaker A's utterance may be caused by the verbal context, which is insufficient to interpret the meaning of a polysemous word (see example 5) as well as 
features of its syntactic structure: in discourse fragment (6) the verb in the utterance is perceived as transitive with an implicit object, which triggers misunderstanding.

(5) Robert: They're out to get me.

\section{Lisa: Get you what?}

Robert: Get rid of me ("Come September").

(6) Lady Frances: So, that's it? If only you knew!

Roger Bassington-ffrench: Knew what?

Lady Frances: I can't tell you at the moment. But please trust me ("Why didn't they ask Evans?").

Studies on the discourse level concentrate on establishing relations between utterances, namely coreference (functioning of anaphoric expressions), and semantic (temporal, causal, etc.) relations between propositions (Garnham 2005: 246), i.e., cohesion. Discourse comprehension is considered to involve both the interlocutor's utterance and its meaning (bottom up processing), and the communicator's knowledge/expectations (top down processing), which, taken together, enable him/her to make assumptions about what was meant on the pragmatic level (van Dijk 1984: 12).

From the viewpoint of discourse production, an utterance may be studied on the level of locutionary act, which includes phonetic act (uttering certain sounds), phatic act (pronouncing words as part of a certain vocabulary in accordance with the corresponding grammar rules), and rhetic act ("the utterance of certain words in a certain construction" "with a certain sense and with a certain reference", which constitutes "meaning" (Austin 1962: 93-95)), illocutionary act, and perlocutionary act/perlocution (the interlocutor's next action (Thomas 1995: 49)) (Austin 1962: 94107). Illocutionary act, according to Searle, consists of propositional content (reference and predication) and illocutionary point (Searle 1965). 
If we consider a speech act (stimulus utterance) in terms of its comprehension, an echo question may point to difficulty in understanding the stimulus on different levels. Identifying the reference of a noun/pronoun may pose problems in the following cases:

a) an anaphoric personal pronoun is used when the antecedent is absent/ambiguous or has an exophoric referent:

(7) Margot: I've seen him.

Jim: Who?

Margot: Roddy ("Always goodbye").

b) a cataphoric personal pronoun is used in a cleft construction:

(8) Miss Marple: Well, talk to her again because I think there's more to come. She, er, she brought me kippers this morning, instead of herrings, and forgot the milkjug. You see, he may have told her who it was.

Inspector Craddock: I'm sorry, who what was?

Miss Marple: Well, who it was put him up to it ("A murder is announced").

c) a demonstrative pronoun is followed by a noun inactive in the consciousness of speaker B (Chafe's term (1987: 22)):

(9) Franky: Oh, we've had marks, haven't we? How did they get you? Was it after you wrote that letter?

Bobby: What letter?

Franky: Telling me how to get here.

Bobby: I never wrote you a letter ("Why didn't they ask Evans?").

d) an indefinite noun in the singular/plural or a noun with a broad meaning (thing, matter) provides insufficient information:

(10) McKenzie: I'm not quite clear what this is about, MisterHercule Poirot: A friend advised me to get in touch with you. 


\section{McKenzie: Friend? What friend?}

Hercule Poirot: He prefers to remain anonymous.

McKenzie chuckles: Oh, yes. I don't think I care for anonymous friends ("The Plymouth Express").

e) a possessive pronoun whose antecedent is ambiguous (several interpretations are possible) is used with a noun:

(11) Bobby: Now, someone please tell me what's going on!

Franky: Roger Bassington-ffrench. I'm on the track. Merroway Court belongs to his brother and he lives there with him and his American wife.

Bobby: Whose wife?

George Arbuthnot: The brother's, of course ("Why didn't they ask Evans?").

f) the referent of a proper name is inactive in speaker B's consciousness or unknown to him/her:

(12) Inspector Craddock: A shifty eye?

Miss Marple: Yes. The kind that looks straight at you and never blinks. It reminded me of Fred Tyler.

\section{Inspector Craddock: Should I know Fred Tyler?}

Miss Marple: Oh, no. No, no. He worked at the fish shop in my village. Always adding an extra one to the shillings column ("A murder is announced").

Predication (as a "process and result of linguistically assigning qualities to persons, animals, objects, events, actions and social phenomena", their characterization "with respect to quality, quantity, space, time, and so on" (Reisigl \& Wodak 2001: 54)) may also trigger the use of echo questions. Misunderstanding or surprise may be caused by certain characteristics of events, an interlocutor's emotional state, a past action (performed by the interlocutor/other person or on him/her) or the communicators' status and roles. Consider the example: 
(13) Bill: It's all over.

Margo: What's all over?

Bill: The audition. Eve read with Miss Casswell.

Margo: Eve? How enchanting! However did you two get the idea of letting Eve read with Miss Casswell?

Lloyd: Well, she's your understudy.

Margo: Eve? My understudy? I had no idea.

Lloyd: I thought you knew. She was put on a week ago ("All about Eve").

In the given communicative situation, echo questions uttered by the actress Margo Channing express feigned surprise at the news that her understudy (Eve) substituted for her during Miss Casswell's audition. Pretending not to know anything about Eve's successful performance, which was described to her by a theatre critic who attended it, Margo is trying to find out as much as possible about Bill's and Lloyd's impressions to plan her behaviour in the future.

When determining the illocutionary force of the interlocutor's utterance, speaker B takes into account its meaning and the communicators' common contextual beliefs (Bach \& Harnish 1979: 6), which may be viewed as a component of the mental context model. In the following exchange, the illocutionary force of Lady Runcorn's utterance is to elaborate on the information provided by Marcus Hardman about Martin Johnstone as his colleague:

(14) Marcus Hardman: Oh, let me introduce you to a colleague of mine from South Africa. Martin Johnstone, Lady Runcorn.

Martin Johnstone: How do you do?

Marcus Hardman: Excuse me.

Lady Runcorn: Are you also a collector, Mr Johnstone?

Martin Johnstone: What? 
Lady Runcorn: Jewellery. Mr Hardman has one of the finest collections in England ("The double clue").

In this case, the echo question indicates misunderstanding of the meaning of the interlocutor's question, which Lady Runcorn clarifies by asking Martin Johnstone to specify Marcus Hardman's occupation as a possible sphere of business cooperation. Compare with situation (15).

(15) Father Brown: You and Audrey MacMurray, you were close, weren't you?

\section{Gary Bakewell: Is that a question or statement?}

Father Brown: More of a statement, really. A friend of mine said you walked in on him and Audrey at rather an inopportune moment, shall we say? And that you seemed very upset ("The laws of motion").

In this case, the reason for misunderstanding lies not in the meaning of Father Brown's question, but its illocutionary force (question or statement), which correlates with the speaker's degree of certainty about the utterance. Father Brown's reaction to the echo question serves to explicate his communicative intention and grounds for holding such an opinion. Inability to recognize the interlocutor's communicative intention and the locutionary/illocutionary meaning finds expression in the following ways: What do you mean (by this/that)?, What are you saying?, What are you suggesting?, What are you talking about?, I beg your pardon?.

Comprehension problems may be related to the felicity conditions of a speech act (Austin 1962: 12-47), namely the interlocutor's sincerity when uttering a statement or a promise (Searle 1965): No kidding?, Are you kidding?, Is it a joke?, Are you being funny?, Seriously? and his/her right to perform the speech act in question (asking, asserting, commanding) (Austin 1962: 132-146; van Dijk 1977: 200-201). When the sincerity condition is violated, echo questions express doubt, disbelief or hesitation, 350

ISSN 2453-8035

DOI: 10.1515/lart-2017-0009 
whereas evaluating the interlocutor's utterance in terms of his/her "status, position and power" (van Dijk 1977: 200) and the contextual assumptions about his/her rights may lead to an emotional expression of indignation (How dare you?), refusal (Who says you make conditions? ("That darn cat"), Is there any reason why I should? ("Four and twenty blackbirds"), Can't? Who on earth do you think you're talking to? ("The three tools of death")) or misunderstanding:

(16) Miss Blacklock: Nobody is coming to kill anybody. It's just a joke!

Hannah: Murdering people is a joke! In England everything is a joke. In Europe, killing people is not a joke. That is why I escaped.

Miss Blacklock: I promise you, my dear, you are perfectly safe.

Hannah: You promise?

Miss Blacklock: If somebody was going to murder you, they'd hardly advertise the fact in the newspaper ("A murder is announced").

Hannah is employed as a cook in Miss Blacklock's house and finds out from an anonymous newspaper advertisement that there is going to be a murder there. Concerned about her safety, Hannah is trying to leave the position, but Miss Blacklock assures her that her life is in no danger, perplexing Hannah because giving such a promise means having control over the situation.

Apart from the explicit message, misunderstanding may be caused by the implicit information ("the content, which is not expressed in the usual lexical and grammatical meanings of the language units constituting an utterance, but can be derived from the latter when it is perceived" (Долинин 1983: 37)), namely presuppositions and implications (van Dijk 2014: 52).

Presupposition is defined as information considered to be "common ground among the participants in the conversation" (Stalnaker 2002: 701). According to the linguistic 
means, which can express potential presuppositions, Yule identifies the following types of presuppositions (1996: 27-30):

- existential presupposition (the referent of a possessive construction or a definite noun phrase is assumed to exist):

(17) Dinah Fortescue: I want it absolutely understood that I've never forgiven myself for what I did, not only to Bert Evans, but his wife and their poor little boy.

Mrs McCarthy: Albert Evans had a son? ("The daughters of Jerusalem").

Mrs McCarthy is surprised and asks for more details regarding the presupposed information about Albert Evans' son, expressed by a possessive pronoun and a noun, which was in fact unknown to her.

- factive presupposition (the information following such verbs as know, regret, be aware/odd/glad "can be treated as a fact"):

(18) Ann: Why did you come?

Jerrold: I've been terribly worried about you, darling. I wanted to be sure you were safe.

\section{Ann: Why did you think I might not be safe?}

Jerrold: Ann, whatever has come over you? ("The adventures of Sherlock Holmes").

Ann's misunderstanding is caused by her fiancé's presupposed doubt about her safety.

- $\quad$ non-factive presupposition (information following such verbs as dream, imagine, pretend is assumed to be not true):

(19) Inspector Craddock: I'm going to ask the ladies present to tell me what they were doing today between the hours of eleven o'clock and noon. Starting with the young lady who's been calling herself Julia Simmons.

Mrs Swettenham: Calling herself? 
Edmund Swettenham: Hush, Mother ("A murder is announced").

In this situation, the non-factive presupposition, expressed by Inspector Craddock, makes Mrs Swettenham feel cognitive dissonance, which urges her to establish who the girl considered to be Julia Simmons is, along with her real name.

- lexical presupposition ("the use of one form with its asserted meaning is conventionally interpreted with the presupposition that another (non-asserted) meaning is understood"):

(20) Eric Landry: Do you think about your Mom a lot?

Kelli: I guess. She'd be more understanding about this.

Eric Landry: Well, I imagine Belle'll be understanding too.

Kelli: Maybe. I think she overdoes it, you know, trying to make up for Mom. Don't get me wrong. I'm glad Belle's around. Things would've been way bad if she hadn't come back.

\section{Eric Landry pauses: Come back?}

Kelli: She was in California at school. When Mom died, she came back here ("Beauty and the beast: A latter-day tale").

Eric Landry collects Kelly (his assistant Belle's sister) from school. Kelly complains that she has been unfairly scolded by the headmaster for cheating, adding that of all her relatives her mother would have understood her feelings best. When Kelly speaks about Belle's return, Eric is puzzled because come back presupposes first leaving the place, while Eric knows nothing about Belle's life and studies in another city.

- $\quad$ structural presupposition (the information is true due to being expressed by part of a certain structure):

(21) Nicole Bonnet: Temporarily, you'll have to go straight. Look, it's late and I'm tired, and I have to work in the morning. 


\section{Simon Dermott: You work?}

Nicole Bonnet: Some people do, you know ("How to steal a million").

At night Simon Dermott enters Charles Bonnet's house (a renowned collector and artist) pretending to be a burglar in order to establish the authenticity of one of Bonnet's paintings. Hearing a suspicious sound in the house, Charles' daughter Nicole arms herself with a revolver and goes to see what has caused it. Having injured Simon's right arm accidentally, Nicole dresses his wound, and Simon complains that now he will not be able to pursue his career. His ideas about the Bonnets' wealth conflict with Nicole's presupposition that she needs to work, which she confirms by positioning herself as an honest law-abiding citizen, unlike Simon.

- $\quad$ counterfactual ("a counterfactual conditional" "presupposes that the information in the if-clause is not true at the time of the utterance" (Yule 1996: 29)). The linguistic material subjected to analysis contains no examples of counterfactual presupposition in the stimulus utterance, however, the use of the following conditional sentence is noteworthy:

(22) Chief Inspector Morse: I want to know what Quinn's colleagues were doing on Friday afternoon.

Sergeant Lewis: All right.

Chief Inspector Morse: But I want them to know I want to know.

Sergeant Lewis: But if you do that-

Chief Inspector Morse: They'll all have their stories ready. Precisely. Let's see what they cook up.

Sergeant Lewis: All right. So, whoever killed Quinn will have a pretty good alibi for last Friday. That should help, I admit.

Chief Inspector Morse: If Quinn was killed on Friday.

Sergeant Lewis: Wasn't he?

Chief Inspector Morse: I don't know. Do you? ("The silent world of Nicholas Quinn"). 
If Quinn was killed on Friday is a presupposition for having an alibi for the time of the murder on Friday. Placing emphasis on the conjunction casts doubt on the presupposition by expressing a disjunction: Quinn was killed or Quinn was not killed on Friday, which causes misunderstanding and urges Lewis to resolve the ambiguity.

Proceeding from the assumption that successful communication is ensured by following P. Grice's Cooperative Principle (Grice 1989: 30), the speaker's failure to observe the maxims of quantity, quality, relation, and manner (Grice 1989: 26) may be regarded as another cause of misunderstanding. The quantity maxim is violated if the stimulus utterance is not enough informative, which can be combined with formal superfluousness (e.g., repetitions, tautologies).

(23) Bobby: You know what annoys me most about this business?

Franky: What?

Bobby: Being hurtled into the next world without knowing who Evans is ("Why didn't they ask Evans?").

According to its structural and functional characteristics, Bobby's utterance belongs to "cognitively significant metacommunicative signals", which intensify perception (Чхетиани 1987), but contains insufficient information, thus urging Franky to employ an echo question for clarification.

If the interlocutor (A) fails to observe the quality maxim (Grice 1989: 27), speaker B expresses doubt about the truth of A's utterance (example 24) or the grounds for a particular assertion: Are you quite sure? (Kate and Leopold), How can you be so sure? (The Pelican Brief), What makes you so sure? ("The shadow of the scaffold").

(24) Marcel: Good afternoon.

Davis Leland: Just tell Miss Bonnet that I'm here, will you please? 
Marcel: I'm sorry, sir. Miss Bonnet has gone out.

Davis Leland: Out? Are you sure? Her car is in the courtyard.

Marcel: Quite sure, sir. She, er, took a taxi ("How to steal a million").

Davis Leland's echo questions are triggered by the problematic credibility (Березенко 2003) of Marcel's utterance, who, acting on Nicole Bonnet's orders, provides false information about her absence.

Violation of the relevance maxim involves both a sudden change of the topic under discussion and the use of allusions:

(25) Sir Aaron Armstrong: Alice? Please, speak to me. I only ever wanted what was best for you.

Alice: Joan of Arc.

Sir Aaron Armstrong: What?

Alice: What you let them do to me. It's like being burnt alive ("The three tools of death").

After his daughter Alice has been subjected to electric shock treatment meant to improve her mental health, Sir Aaron Armstrong tries to persuade her to talk to him, expecting a mundane answer. Therefore, reference to Joan of Arc is perceived as irrelevant, and Alice is asked to elaborate on the implicit reproach.

Violations of the manner maxim, manifested by unclarity and ambiguity (Grice 1989:

27) of the stimulus utterance, also hinder understanding:

(26) Alfons: It wasn't a threat, it was a warning.

Mrs McCarthy: Father Brown heard it himself, he was standing right there.

Inspector Sullivan: Father, can you verify this? 
Father Brown: I don't think anybody was acting reasonably yesterday morning. Inspector Sullivan: Father Brown, did you see this man threaten Jeremiah Moxley the day he died?

Father Brown: I saw something of the sort ("The Kembleford boggart").

Mrs McCarthy accuses Alfons (a member of a group of travelling gypsies) of Jeremiah Moxley's murder, stating that he threatened the latter in the presence of witnesses on the day he died. Using a generalization, Father Brown attempts to throw suspicion off Alfons, whom he considers innocent. However, his reply violates the maxims of quantity and manner and cannot be accepted as conclusive evidence by the police, which is why Inspector Sullivan specifically asks Father Brown whether Alfons' utterance can be considered a threat.

It is worth noting that discourse comprehension and building its mental model/representation presuppose "integration of information from the discourse and the comprehender's knowledge and cognitive activities" (Zwaan \& Rapp 2006: 737). In cognitive studies, three levels or types of mental representations are distinguished: the surface structure (a word-for-word representation of the text, which is forgotten quickly unless it is pragmatically relevant); the textbase or propositional representation ("idea units explicitly stated in the text, along with some bridging inferences"); and the situation model (information from the text complemented by background knowledge) (Zwaan \& Rapp 2006: 737). "Knowledge consists of a system of concepts organized by categorical relationships" and "by more complex schemata or scripts". Types of knowledge distinguished according to a set of criteria include declarative/procedural, social (shared)/personal, general/specific, abstract/concrete, fictional/real (van Dijk 2012: 588). Background knowledge functions as the basis for interpreting new information (Zwaan \& Rapp 2006: 737), whereas inconsistencies between them lead to misunderstanding. 
Regarding the use of echo questions, difficulty in representing the surface structure of the interlocutor's utterance is caused by contradictory information:

(27) Div. Insp. Jameson: She gave no hint about contemplating suicide?

Major Eustace: Not the least in the world. As a matter of fact, when we said goodbye, I said I'd ring her up soon and we'd do a show together.

Chief Inspector Japp: You said you'd ring her up? Those were your last words? Major Eustace: Yes.

Chief Inspector Japp: Curious. I have information that you said something quite different. My information is that what you actually said was, "Well, think it over and let me know." Not quite the same thing, is it?

Major Eustace: Well, I- I- I think what I said was that she should let me know when she was free. I mean, you can't expect a man to remember word for word ("Murder in the Mews").

Chief Inspector Japp's echo questions aim at an exact reproduction of the stimulus utterance (a part of Major Eustace's conversation in the past), which, in its turn, is a component of the mental context model (knowledge about the relations between the Major and the woman who committed suicide). The need to verify the Major's statement before integrating it into his knowledge base stems from the Inspector's doubt about Major Eustace's sincerity.

Difficulties in representing the textbase correlate with the types of misunderstanding discussed above (on the level of proposition, communicative intention and implicit information), whereas building a coherent mental situation/context model may be hindered by a lack or discrepancy of (different types of) knowledge.

In discourse fragments (28)-(30) misunderstanding is caused by the contradiction between the interlocutor's utterance and general/culturally specific knowledge. 
(28) Hannah: My last cake, he calls it "Delicious death".

Miss Blacklock: Oh, but that's a compliment!

Hannah: Death is a compliment? shrugs her shoulders ("A murder is announced").

General public attitude to death as a negative phenomenon and a taboo in conversation prevents Hannah from taking the comparison of her culinary masterpiece with death as a compliment.

(29) Elizabeth: I still don't understand what those glasses were doing in your pocket. David: I was taking them down to the tennis court. There was somebody waiting. Erer, there was a game going on .

Elizabeth: In the dark? In the middle of the night?

Linus: Yes. That's why he needed the glasses. Linus laughs.

David laughs: Yes, that's why I needed the glasses ("Sabrina").

Elizabeth's echo questions serve to express distrust of her fiancé's story, which he alters by means of self-correction. Besides, his explanation contradicts her knowledge that a game of tennis normally takes place at daytime and does not require two champagne glasses.

(30) Oona: It wasn't me.

Father Brown: It was written on your typewriter.

Oona: I could, I could never write such a thing.

Father Brown: The police will believe otherwise.

Oona: I can't write English.

Father Brown: What?

Oona: All my education was in Gaelic. I can't read or write English at all ("The Grim Reaper"). 
Taking into account that Oona speaks English and works as a receptionist for her husband (a family doctor), which involves making appointments, Father Brown assumes that she can read and write in English as well.

The interlocutor's utterance may contradict the speaker's knowledge/beliefs or the facts, which the speaker learnt in previous conversations with the same/different interlocutor. Thus, in communicative situation (31) below, Sylvia fails to understand Roger's sudden change of heart about his brother Henry's treatment of substance abuse:

(31) Roger: There are other places, places not so near at hand.

Sylvia: But half an hour ago you were for Henry's going to the Grange. Why have you changed your mind?

Roger: It's simply that I've been thinking it over and I think there are other places ("Why didn't they ask Evans?").

In the following exchange, the discrepancy between the colonel's account of the riding accident in which he lost his eye and the information given previously by his mother leads Father Brown to suggest that the colonel is not the person who he pretends to be: (32) Father Brown: How did you lose your eye?

Colonel Forbes-Leith: A riding accident. I-I fell and my horse kicked out.

Father Brown: Your horse? Lady Edna said it was your father's.

Colonel: I er-You know what her memory's like.

Father Brown: Take off your eye patch ("The truth in the wine").

A further cause of misunderstanding pertains to the interlocutor having certain knowledge (e.g., about the partner in communication, his/her actions, knowledge/beliefs) and its source: What do you mean you know? ("The shop around the corner"), And how is it that you know? ("The Hollow"), How did you know? ("Why didn't they ask Evans?"), How did you know that? ("You've got mail"), How can you know it? ("Triangle at Rhodes"). 
(33) Chief Inspector Japp: You know what's worrying me, Poirot?

Hercule Poirot: Yes.

Chief Inspector Japp: Yes? What do you mean "yes"?

Hercule Poirot: I saw you looking at Mrs Allen's chequebook stubs yesterday.

Chief Inspector Japp: You're too clever for your own good, you are, Poirot ("Murder in the Mews").

Chief Inspector Japp's question is used to introduce a problem, which is why Poirot's affirmative reply results in surprise and the Inspector's request to explain how Poirot has acquired knowledge about the Inspector's reasoning and the difficulties encountered.

The interlocutor's willingness to obtain certain knowledge, which he/she lacks in order to build a mental context model of the communicative situation, may also cause misunderstanding:

(34) Abigail Tillerman: Your cousin in Bridgeports, she thinks you're retarded. Is it true? I'm asking, Maybeth, I'm asking you. Is it true?

Maybeth: I don't think I am. I don't know just what it means. But if it's such a bad thing to be, why do you want to know?

Abigail Tillerman: You have to take it easy for a couple of weeks, okay? ("Homecoming").

Abigail, irritated because her eight-year-old granddaughter Maybeth often remains silent when addressed, expresses doubt about her level of psychological development and assumes that she is retarded. Perceiving the negative connotations of the word from the context, Maybeth asks why her grandmother needs to know the information, which makes Abigail feel ashamed and change the topic of the conversation. 
Discourse comprehension (the interlocutor's utterance or text) is influenced by knowledge structures (frames, scripts, scenarios (Renkema 2004: 236)), which become activated by its lexical and grammatical items (Fillmore 1982: 124). A frame (schema, in Tannen's terms) is defined as "knowledge structures in the minds of participants in interaction - expectations based on prior experience about objects, events, and settings" (Tannen 1985: 328). For instance, in the following communicative situation, the lexeme surgery activates the corresponding frame, which presupposes certain components (slots) and relations between them (Renkema 2004: 236), such as the doctor's table, medical instruments, etc. The presence of a bag for leather work in the late doctor's surgery, mentioned by his widow, is considered to be an unnecessary component whose presence requires additional explanation:

(35) Hercule Poirot: Where is your bag for the leather work, Madame?

Gerda Christow: Oh, I- I think it's in the surgery.

Hercule Poirot: The surgery?

Gerda Christow: I sit there. In his chair. I'll fetch it for you, shall I?

Hercule Poirot: S'il vous plait ("The Hollow").

Misunderstanding may also be caused by lack of an essential component of a frame (e.g., motive for a crime):

(36) Colin McNabb: She was a fascinating case. Was it suicide?

Japp: No, Mr McNabb. It would seem that she's been poisoned.

Colin McNabb: Poisoned?

Japp: With morphine.

Colin McNabb: Morphine? That's not possible.

Japp: Why not?

Colin McNabb: I mean, nobody would want to kill her. Not Celia.

Poirot: Do you speak then of a murder without a motive?

Colin McNabb: Well, look, I don't know ("Hickory dickory dock"). 
Colin's surprise about Celia Austin's poisoning is motivated by his knowledge that he had disposed of the poison and it could not have caused the girl's death. Unwilling to explain what he meant to avoid taking responsibility and throwing suspicion on his peers, Colin does not name a possible murderer.

In the following discourse fragment, misunderstanding is related to frame break (Bublitz \& Lenk 1999: 170-171):

(37) Mrs Mabel Grayson: I certainly didn't kill anyone.

Father Brown: No. But there is a killer in this room. Isn't there?

Gregoire Bisset: Yes, all right. I confess.

Mrs Grayson: Monsieur Bisset!

Gregoire Bisset: But, please, it was an accident. He just ran in front of the car.

Mrs Grayson: The car?

Gregoire Bisset: He just lay there.

Emily Fletcher: What are you on about?

Father Brown: Bacchus. Tom's dog.

Mrs Grayson: Oh! ("The truth in the wine").

The communicators are discussing a murder involving the use of a firearm, whereas the lexeme "car" activates quite another frame (a road accident). Mrs Grayson's echo question The car? indicates misunderstanding triggered off by a sudden change of frame; however, Gregoire Bisset interprets it as a clarification request about the accident, which happened to the dog. In this discourse fragment, the communicative failure is repaired by means of another echo question, which serves to establish the topic under discussion (What are you on about?).

A script "pertains to our knowledge of the role behaviour of participants in stereotypical situations", e.g., the restaurant script (Renkema 2004: 237). Another 
situation - "hiring a private detective" - presupposes that the detective will protect the interests of the client in question:

(38) Poirot: Countess, please allow me to introduce two colleagues of mine, Messieurs Redfern and Blake.

Blake: Good evening, ma'am.

Poirot: They are like myself, private detectives.

Countess Vera Rossakoff: Do you really think I need an escort?

Poirot: No, no, no. They are for your protection. During your short visit in England there have been four very clever robberies. I would not wish you to be involved in a fifth ("The double clue").

The Countess expects the private detectives to act as her bodyguards and considers it unnecessary; however, Poirot engages them in the capacity of law enforcement officers in order to prevent the Countess from committing another jewellery theft in England in the future.

Apart from cases of misunderstanding rooted in different variants of a certain script, stereotypical ideas about role behaviour may come into conflict with the speaker's beliefs:

(39) Mrs Todd: I tell you what I want you to do for me. I want you to find my cook. Poirot: I fear you are making a mistake, Madame. Hercule Poirot is a private detective. Mrs Todd: I know that. Haven't I just told you I want you to find my cook for me? Walked out of the house on Wednesday, without so much as a "bye" and leave and never came back.

Poirot: I'm sorry, Madame, but I do not touch that particular kind of business. I wish you good day ("The adventure of the Clapham cook").

Considering that a private detective must carry out any client's assignments (which are not a breach of the law), Mrs. Todd asks Poirot to find her cook, who has gone missing, 
whereas he considers such a task not important enough and consequently not worthy of his attention.

A scenario "refers to our knowledge about the ordering of activities" (Renkema 2004: 237). For instance, in the following conversation, taking place before motor races, Mrs. McCarthy is wondering about the particulars of the show:

(40) Mrs. McCarthy: I don't understand this. How are they all supposed to fit on one track?

Inspector Sullivan: They don't, Mrs. McCarthy. They go one at a time.

Mrs. McCarthy: One at a time?

Inspector Sullivan: The clue's in the title. Thousand-yard uphill track. The fastest to make it to the top is the winner.

Mrs. McCarthy: Well, it sounds very dull to me.

Inspector Sullivan: I can assure you, it's far from that. And not a cream tea in sight ("The laws of motion").

Mrs. McCarthy's misunderstanding is caused by her unfamiliarity with the "uphill racing" scenario and subsequent interpretation of the situation as involving a simultaneous race of the participants.

Apart from knowledge structures about the world, schemas (frames) include information regarding linguistic/paralinguistic features of the utterance, which identify it as a part of a certain interactive frame (e.g., joke, insult, disciplining someone, etc.) (Tannen 1985: 327-329). Frame- and register-breaks lead to communicative failures (Bublitz \& Lenk 1999: 171). Consider the following example.

(41) Kate Dawn is on the air, seeing Chief Inspector Morse in another room: Inspector? Chief Inspector Morse: I think we'd better talk outside, Kate.

Kate Dawn: I'm on the air. 
Chief Inspector Morse: Nevertheless.

Kate Dawn: Okay. So, what is so important I had to leave my programme?

Chief Inspector Morse: Katherine Dawn, I charge you with the murder of your husband Anthony John William Dawn. You have the right to speak, but I must warn you anything you say may be taken down and used in evidence.

Kate Dawn: What?

Chief Inspector Morse: I'm sorry.

Kate Dawn: What? ("Deceived by flight").

In this communicative situation, Kate Dawn's misunderstanding and astonishment are caused by Inspector Morse's unexpected utterance both in terms of its form (an official formula recited by the police when an arrest is made compared with colloquial phrases at the beginning of the conversation) and meaning: Morse's attitude to Kate as a grieving widow gives way to charging her with her husband's murder.

Types of misunderstandings resolved by echo questions have been summarized in the table below (see Table 1).

Table 1. Use of echo questions according to types/levels of misunderstanding

\begin{tabular}{|l|l|}
\hline \multicolumn{1}{|c|}{ Criteria } & \multicolumn{1}{c|}{ Levels of misunderstanding } \\
\hline $\begin{array}{l}\text { levels of discourse } \\
\text { processing }\end{array}$ & $\begin{array}{l}\text { word identification } \\
\text { vocabulary } \\
\text { syntactic structure } \\
\text { discourse }\end{array}$ \\
\hline $\begin{array}{l}\text { components of a speech } \\
\text { act (from the viewpoint of } \\
\text { its perception) }\end{array}$ & $\begin{array}{l}\text { reference } \\
\text { predication } \\
\text { meaning } \\
\text { illocutionary force } \\
\text { felicity conditions } \\
\text { implicit information }\end{array}$ \\
\hline $\begin{array}{l}\text { levels/types of a mental } \\
\text { model }\end{array}$ & $\begin{array}{l}\text { surface structure } \\
\text { textbase/propositional representation } \\
\text { mental model }\end{array}$ \\
\hline
\end{tabular}


Depending on the degree of understanding of the interlocutor's utterance and speaker B's ability to build a coherent mental model of speaker A's discourse, echo questions fall into categories, presented in Table 2 below.

Table 2. The role of echo questions in discourse coherence

\begin{tabular}{|l|l|}
\hline A's discourse is coherent for speaker B & $\begin{array}{l}\text { Speaker B perceives a coherence break in A's } \\
\text { discourse }\end{array}$ \\
\hline $\begin{array}{l}\text { echo questions are employed to build a } \\
\text { coherent mental context model thereof, } \\
\text { elaborating on its components }\end{array}$ & $\begin{array}{l}\text { echo questions restore discourse coherence, } \\
\text { asking for clarification } \\
\text { on different levels of } \\
\text { - discourse processing, } \\
\text { - the mental model; } \\
\text { regarding the components of the speech act } \\
\text { being perceived }\end{array}$ \\
\hline
\end{tabular}

\section{Discussion and conclusions}

The aim of the research was to elucidate the role of echo questions as a means of increasing coherence in conversational discourse by resolving misunderstanding and offer a typology of the latter. Applying van Dijk's sociocognitive theory and cognitive discourse analysis to studying echo questions in conversational discourse, we have established that echo questions in conversational discourse are used to build/update a mental context model of the communicative situation (i.e., inquire about such components of the mental model as the interlocutor's personality, his/her status and role, knowledge, beliefs, expectations, intentions, plans, attitudes, emotions, and the subject being discussed).

As discourse comprehension presupposes building its coherent mental model, misunderstanding is regarded as a coherence break (communicative failure) corrected by means of echo questions. In the article, types of misunderstanding have been systematized according to the levels of discourse processing distinguished in psycholinguistics (word identification, vocabulary (not knowing a word), syntactic structure, and discourse), components of a speech act from the viewpoint of its perception: reference (the referent is inactive in the speaker's consciousness, unknown 
or ambiguous), predication, meaning, illocutionary force, felicity conditions (the interlocutor's sincerity and his/her right to perform the speech act in question), implicit information (presuppositions and implicatures resulting from violations of P. Grice's Cooperative Principle and its subsequent maxims (quantity, quality, relation, and manner)), levels/types of a mental model: the surface structure, the textbase/propositional representation, and the mental model, involving knowledge. The use of echo questions on the level of representing the surface structure is motivated by the speaker's need to check the information before adding it to his/her knowledge base; types of problems with the propositional representation coincide with those concerning comprehension of a speech act; building a coherent mental model may be hindered by contradictions of the speaker's knowledge (general, cultural, situation-specific) and the incoming information, provided by the interlocutor.

The results obtained in the study may be used in further research on the functioning of echo questions as a means of coherence-building in different types of discourse (e.g., institutional and cross-cultural communication), whereas its practical implications involve language teaching (namely echo questions as an instrument of discourse management in speaking).

\section{References}

Austin, J.L. (1962). How to do things with words. Oxford: Oxford University Press.

Bach, K. \& Harnish, R.M. (1979). Meaning, speech acts and communication. Cambridge, Massachusetts: The MIT Press.

Berezenko, V. (2003). Credibility as a parameter of the constative utterance and means of its expression in Modern English. Thesis for the Candidate Degree in Philology, Speciality 10.02.04 - Germanic Languages. Kyiv National Linguistic University, Kyiv. / Berezenko, V. Virohidnist' yak parametr konstatyvnoho vyslovlyuvannya ta zasoby yiyi vyrazhennya v suchasnij anhlijs'kij movi. Dysertatsiya na zdobuttya vchenoho stupenya kandydata filolohichnyx nauk. Kyivs'kyj 368 ISSN 2453-8035

DOI: 10.1515/lart-2017-0009 
natsional'nyj linhvistychnyj universytet, Kyiv. / Березенко В.М. Вірогідність як параметр констативного висловлювання та засоби ї̈ вираження в сучасній англійській мові / Дис. ... канд. філол. наук / Київський національний лінгвістичний університет. 10.02.04 - германські мови. Київ.

Bublitz, W. \& Lenk, U. (1999). Disturbed coherence: 'Fill me in'. In Coherence in spoken and written discourse: how to create it and how to describe it: Selected papers from the international workshop on coherence, Augsburg, 24-27 April 1997. Bublitz, W., Lenk, U. \& Ventola, E. (eds.). Amsterdam-Philadelphia: John Benjamins, p. 153174.

Carter, R. \& McCarthy, M. (2006). Cambridge grammar of English. Cambridge: Cambridge University Press.

Chafe, W. (1987). Cognitive constraints on information flow. In Coherence and grounding in discourse: Outcome of a symposium. Tomlin, R.S. (ed.). Eugene, Oregon, June 1984. Amsterdam: John Benjamins, p. 21-51.

Chkhetiani, T.D. (1987). Linguistic aspects of phatic metacommunication. Thesis for the Candidate Degree in Philology, Speciality 10.02.04 - Germanic Languages. Kyiv National Linguistic University, Kyiv. / Chhetiani, T.D. Lingvisticheskie aspekty faticheskoj metakommunikatsii. Dissertatsiya na soiskaniye uchenoj stepeni kandidata filologicheskix nauk. Kiyevskij natsional'nyj lingvisticheskij universitet. Kiyev. / Чхетиани Т.Д. Лингвистические аспекты фатической метакоммуникации / Дисс. ... канд. филол. наук / Киевский национальный лингвистический университет. 10.02.04 - германские языки. Киев.

van Dijk, T.A. (2000). Cognitive discourse analysis: An introduction. Available at: http://www.discursos.org/unpublished\%20articles/cogn-dis-anal.htm

van Dijk, T.A. (1999). Context models in discourse processing. In The construction of mental representations during reading. Van Oostendorp, H. \& Goldman, S.R. (eds.). Mahwah, NJ: Lawrence Erlbaum Associates, p. 123-148. 
van Dijk, T.A. (2015). Critical discourse studies: A sociocognitive approach. In Methods of critical discourse analysis. Wodak, R. \& Meyer, M. (eds.). $3^{\text {rd }}$ ed. London: Sage, p. 63-85.

van Dijk, T.A. (1984). Dialogue and cognition. In Cognitive constraints on communication: Representations and processes. Vaina, L. \& Hintikka, J. (eds.). Dordrecht: D. Reidel Publishing Company, p. 1-17.

van Dijk, T.A. (2008). Discourse and context: A sociocognitive approach. New York: Cambridge University Press.

van Dijk, T.A. (2012). Discourse and knowledge. In The Routledge handbook of discourse analysis. Gee, J.P. \& Handford, M. (eds.). London: Routledge, p. 587-603. van Dijk, T.A. (2014). Discourse and knowledge: A sociocognitive approach. Cambridge: Cambridge University Press.

van Dijk, T.A. \& Kintsch, W. (1983). Strategies of discourse comprehension. New York: Academic Press.

van Dijk, T.A. (1977). Text and context: Explorations in the semantics and pragmatics of discourse. New York: Longman.

Dolinin, K.A. (1983). Implicit content of the utterance. In Topics in the study of language, 6, p. 37-47. / Dolinin, K.A. Implitsitnoye soderzhaniye vyskazyvaniya. In Voprosy yazykoznaniya, 6, s. 37-47. / Долинин К.А. Имплицитное содержание высказывания. In Bonросы языкознания, 6, с. 37-47.

Doyle, A.C. (1993). The case-book of Sherlock Holmes. Ware: Wordsworth Editions Limited.

Dynel, M. (2014). On the part of ratified participants: Ratified listeners in multi-party interactions. In Brno studies in English, 40 (1), p. 27-44.

Fillmore, C.J. (1982). Frame semantics. In Linguistics in the Morning Calm: Selected papers from SICOL-1981. Seoul: Hanshin Publishing Company, p. 111-137.

Garnham, A. (2005). Language comprehension. In Handbook of cognition. Lamberts, K. \& Goldstone, R.L. (eds.). London: Sage Publications, p. 241-254. 
Grice, P. (1989). Studies in the way of words. Cambridge, Massachusetts: Harvard University Press.

Huddleston, R. (1984). Introduction to the grammar of English. Cambridge: Cambridge University Press.

Leech, G. (2006). A glossary of English grammar. Edinburgh: Edinburgh University Press.

Leech, G. \& Short, M. (2007). Style in fiction: A linguistic introduction to English fictional prose. $2^{\text {nd }}$ ed. Harlow: Pearson Education Limited.

McCawley, J.D. (1998). The syntactic phenomena of English. $2^{\text {nd }}$ ed. Chicago: The University of Chicago Press.

Quaglio, P. (2009). Television dialogue: The sitcom Friends vs. natural conversation. Amsterdam-Philadelphia: John Benjamins Publishing Company.

Radford, A. (2009). An introduction to English sentence structure. Cambridge: Cambridge University Press.

Reis, M. (2012). On the analysis of echo questions. In Tampa papers in linguistics, 3, p. 1-24.

Reisigl, M. \& Wodak, R. (2001). Discourse and discrimination: Rhetorics of racism and antisemitism. London: Routledge.

Renkema, J. (2004). Introduction to discourse studies. Philadelphia: John Benjamins Publishing Company.

Santorini, B. \& Kroch, A. (2007). The syntax of natural language: An online introduction using the Trees program. Available at: http://www.ling.upenn.edu/ beatrice/syntax-textbook/

Schiffrin, D. (2006). Discourse marker research and theory: revisiting and. In Approaches to discourse particles. Fischer, K. (ed.). Amsterdam: Elsevier, p. 315-338. Searle, J. (1965). What is a speech act? In Philosophy in America. Black, M. (ed.). London: Allen and Unwin, p. 221-239. 
Sobin, N. (1989). Echo question formation in English. In Proceedings of the Western conference on linguistics, 2. Brengelman, F.H., Samiian, V. \& Wilkins, W. (eds.). Fresno, California: California State University, p. 310-317.

Sobin, N. (2009). Echo question syntax. Available at: https://www.researchgate.net/publication/308690021_Echo_Question_Syntax

Stalnaker, R. (2002). Common ground. In Linguistics and Philosophy, 25, p. 701-721. Strelchenko, N.S. (2016). Cognitive peculiarities of echo questions' functioning: mental models. In Science and education a new dimension. Philology, 18 (80), p. 9093. / Strel'chenko, N.S. Kohnityvni osoblyvosti funktsionuvannya pytan'-perepytiv: mental'ni modeli. In Science and education a new dimension. Philology, 18 (80), s. 9093. / Стрельченко Н.С. Когнітивні особливості функціонування питань-перепитів: ментальні моделі. In Science and education a new dimension. Philology, 18 (80), с. 90-93.

Strelchenko, N.S. (2015). Echo questions from the terminological point of view. In Scientific papers. Series: Philology (Linguistics), 138, p. 243-248. / Strel'chenko, N.S. Pytannya-perepyty $\mathrm{v}$ terminolohichnomu aspekti. In Naukovi zapysky. Seriya: Filolohichni nauky (Movoznavstvo), 138, s. 243-248. / Стрельченко Н.С. Питанняперепити в термінологічному аспекті. In Наукові записки. Серія: Філологічні науки (Мовознавство), 138, с. 243-248.

Tannen, D. (1985). Frames and schemas in interaction. In Quaderni di semantica, 6(2), p. 326-335.

Taylor, C.J. (2004). The language of film: Corpora and statistics in the search for authenticity. "Notting Hill" (1998) - A case study. In Miscelánea: A journal of English and American studies, 30, p. 71-85.

Teschner, R.V. \& Evans, E.E. (2007). Analyzing the grammar of English. $3^{\text {rd }} \mathrm{ed}$. Washington, D. C.: Georgetown University Press.

Thomas, J. (1995). Meaning in interaction: An introduction to pragmatics. New York: Routledge.

Yule, G. (1996). Pragmatics. Oxford: Oxford University Press. 
Zwaan, R.A. \& Madden, C.J. (2004). Updating situation models. In Journal of experimental psychology: Learning, memory, and cognition, 30, p. 283-288.

Zwaan, R.A. \& Radvansky, G.A. (1998). Situation models in language comprehension and memory. In Psychological bulletin, 123 (2), p. 162-185.

Zwaan, R.A. \& Rapp, D.N. (2006). Discourse comprehension. In Handbook of psycholinguistics. Traxler, M.J. \& Gernsbacher, M.A. (eds.). $2^{\text {nd }}$ ed. New York: Elsevier, p. 725-764.

\section{Notes:}

The corpus of the analyzed data comprises 92 films dating from 1934 to 2015 and was chosen to represent as many different speakers (both actors and characters) using echo questions as possible. Table 3 below (in the abridged form) provides the list of films and information about their production (genre, director, year, country, length).

Table 3. List of films featuring echo questions used in the study (metadata are based on the information provided by Internet Movie Database)

\begin{tabular}{|c|c|c|c|c|c|c|c|}
\hline No & Title & \begin{tabular}{|c|} 
Motion \\
picture/ \\
Series $(\mathbf{M} / \mathrm{S})$ \\
\end{tabular} & Genre & Director & Year & Country & $\begin{array}{c}\text { Length } \\
\text { (min) }\end{array}$ \\
\hline 1 & $\begin{array}{l}\text { Beauty and the } \\
\text { beast: A latter-day } \\
\text { tale }\end{array}$ & M & drama, romance & \begin{tabular}{|l|} 
Alexander, \\
B.J. \& Brough, \\
B.
\end{tabular} & 2007 & USA; WisenQuest & 91 \\
\hline 2 & $\begin{array}{l}\text { A walk in the } \\
\text { clouds }\end{array}$ & $\mathrm{M}$ & drama, romance & Arau, A. & 1995 & $\begin{array}{l}\text { USA/Mexico; } \\
\text { Zucker Brothers } \\
\text { Productions } / 20^{\text {th }} \text { Century } \\
\text { Fox }\end{array}$ & 102 \\
\hline 3 & $\begin{array}{l}\text { The truth in the } \\
\text { wine }\end{array}$ & $\begin{array}{l}\text { S (Father } \\
\text { Brown) }\end{array}$ & $\begin{array}{l}\text { crime, drama, } \\
\text { mystery }\end{array}$ & Barber, I. & 2015 & UK: BBC & 45 \\
\hline 4 & Fat chance & $\begin{array}{l}\text { S (Inspector } \\
\text { Morse) }\end{array}$ & $\begin{array}{l}\text { crime, drama, } \\
\text { mystery }\end{array}$ & Battersby, R. & 1991 & UK: Zenith Entertainment & 104 \\
\hline 5 & Dumb witness & $\begin{array}{l}\text { S (Agatha } \\
\text { Christie's } \\
\text { Poirot) } \\
\end{array}$ & $\begin{array}{l}\text { drama, mystery, } \\
\text { crime, thriller }\end{array}$ & Bennett, E. & 1996 & $\begin{array}{l}\text { UK: Carnival Film \& } \\
\text { Television }\end{array}$ & 103 \\
\hline 6 & $\begin{array}{l}\text { The adventure of } \\
\text { the Clapham cook }\end{array}$ & $\begin{array}{l}\text { S (Agatha } \\
\text { Christie's } \\
\text { Poirot) } \\
\end{array}$ & $\begin{array}{l}\text { drama, mystery, } \\
\text { crime, thriller }\end{array}$ & Bennett, E. & 1989 & $\begin{array}{l}\text { UK: London Weekend } \\
\text { Television / Independent } \\
\text { Television }\end{array}$ & 51 \\
\hline 7 & Last seen wearing & $\begin{array}{l}\text { S (Inspector } \\
\text { Morse) }\end{array}$ & $\begin{array}{l}\text { crime, drama, } \\
\text { mystery }\end{array}$ & Bennett, E. & 1988 & UK: Zenith Entertainment & 103 \\
\hline 8 & $\begin{array}{l}\text { Murder in the } \\
\text { Mews }\end{array}$ & $\begin{array}{l}\text { S (Agatha } \\
\text { Christie's } \\
\text { Poirot) } \\
\end{array}$ & $\begin{array}{l}\text { drama, mystery, } \\
\text { crime, thriller }\end{array}$ & Bennett, E. & 1989 & $\begin{array}{l}\text { UK: Picture Partnership } \\
\text { Productions }\end{array}$ & 51 \\
\hline 9 & The dream & $\begin{array}{l}\text { S (Agatha } \\
\text { Christie's } \\
\text { Poirot) } \\
\end{array}$ & $\begin{array}{l}\text { drama, mystery, } \\
\text { crime, thriller }\end{array}$ & Bennett, E. & 1989 & $\begin{array}{l}\text { UK: Picture Partnership } \\
\text { Productions }\end{array}$ & 50 \\
\hline
\end{tabular}




\begin{tabular}{|l|l|l|l|l|l|l|l|}
\hline 10 & The yellow iris & $\begin{array}{l}\text { S (Agatha } \\
\text { Christie's } \\
\text { Poirot) }\end{array}$ & $\begin{array}{l}\text { drama, mystery, } \\
\text { crime, thriller }\end{array}$ & $\begin{array}{l}\text { Barber- } \\
\text { Fleming, }\end{array}$ & 1993 & $\begin{array}{l}\text { UK: Picture Partnership } \\
\text { Productions }\end{array}$ & 50 \\
\hline$\ldots$ & $\ldots$ & $\ldots$ & $\ldots$ & $\ldots$ & $\ldots$ & $\ldots$ \\
\hline 88 & $\begin{array}{l}\text { The daughters of } \\
\text { Cain }\end{array}$ & $\begin{array}{l}\text { S (Inspector } \\
\text { Morse) }\end{array}$ & $\begin{array}{l}\text { crime, drama, } \\
\text { mystery }\end{array}$ & Wise, H. & 1996 & $\begin{array}{l}\text { UK: Carlton UK } \\
\text { Productions }\end{array}$ & 101 \\
\hline 89 & $\begin{array}{l}\text { Twilight of the } \\
\text { gods }\end{array}$ & $\begin{array}{l}\text { S Inspector } \\
\text { Morse) }\end{array}$ & $\begin{array}{l}\text { crime, drama, } \\
\text { mystery }\end{array}$ & Wise, H. & 1993 & UK: Zenith Entertainment & 103 \\
\hline 90 & $\begin{array}{l}\text { How to steal a } \\
\text { million }\end{array}$ & $\mathrm{M}$ & $\begin{array}{l}\text { comedy, crime, } \\
\text { romance }\end{array}$ & Wyler, W. & 1966 & USA: 20th Century Fox & 123 \\
\hline 91 & $\begin{array}{l}\text { Laughter in } \\
\text { paradise }\end{array}$ & $\mathrm{M}$ & comedy & Zampi, M. & 1951 & $\begin{array}{l}\text { UK: Associated British } \\
\text { Picture Corporation }\end{array}$ & 93 \\
\hline 92 & Too many crooks & $\mathrm{M}$ & comedy, crime & Zampi, M. & 1959 & UK: The Rank Organisation & 87 \\
\hline
\end{tabular}

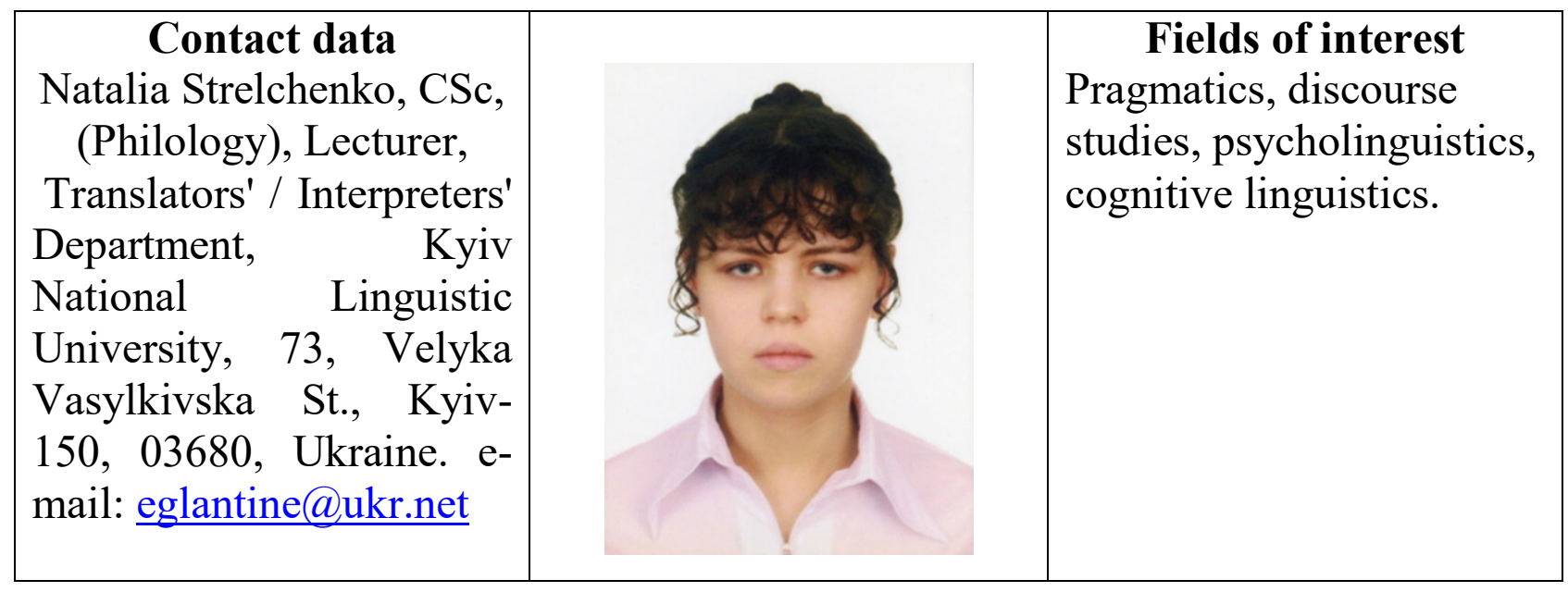

\section{Resume in English}

The paper focuses on the cognitive-communicative characteristics of echo questions in English conversational discourse. Conversational discourse fragments featuring echo questions, selected from British and American films, served as the material for analysis. Drawing on Teun van Dijk's sociocognitive (mental model) theory and cognitive discourse analysis, the paper offers an approach to studying echo questions as a means of building/updating a mental context model of the communicative situation, which constantly controls interaction, or a situation model of a past event, which is regarded as part of the context model (i.e., interlocutors' common knowledge) in the study. Thus, echo questions are employed to elaborate on the components of the mental model currently relevant for the speaker (e.g., the interlocutor's personality, his/her status and role, knowledge, beliefs, expectations, intentions, plans, attitudes, 
emotions, and the subject being discussed). As discourse comprehension presupposes building its coherent mental model, echo questions asking for clarification and thus resolving misunderstanding are regarded as an instrument for increasing coherence in conversational discourse. Types of misunderstandings corrected by echo questions have been systematized in the study according to several criteria: the levels of discourse processing distinguished in psycholinguistics (word identification, vocabulary (unknown lexical items), (ambiguity of the) syntactic structure, and discourse); components of a speech act from the viewpoint of its perception: reference, predication, meaning, illocutionary force, felicity conditions, and implicit information; levels/types of a mental model (of the communicative situation): the surface structure, the textbase/propositional representation, and the mental model, involving knowledge.

Key words: echo question, mental model, discourse comprehension, coherence, misunderstanding, knowledge, conversational discourse.

\section{Résumé in German}

Der vorliegende Artikel befasst sich mit kognitiv-kommunikativen Eigenschaften von Nachfragen im englischsprachigen mündlichen Diskurs. Das Material der Untersuchung umfasst Ausschnitte aus britischen und amerikanischen Spielfilmen, in denen im Rahmen von gesprochenen Diskursen Nachfragen enthalten sind. Basierend auf der soziokognitiven Theorie (mentaler Modelle) von Teun van Dijk und der kognitiven Diskursanalyse, untersucht die Studie Nachfragen als Mittel zur Bildung bzw. Aktualisierung eines mentalen Kontextmodells der Kommunikationssituation, welches die Interaktion kontinuierlich überprüft, sowie eines Situationsmodells bezüglich eines Ereignisses in der Vergangenheit, welches wiederum als Bestandteil eines Kontextmodells (d.h. des allgemeinen Wissens der Kommunikationsteilnehmer) betrachtet wird. Daraus ergibt sich, dass Nachfragen dann erfolgen, wenn sich der Sprecher jener Komponenten des mentalen Modells vergewissern möchte, die für ihn gerade relevant sind (z.B. Angaben zur Person des Kommunikationspartners, sein 
Status und seine Rolle, sein Wissen, seine Überzeugungen, Hoffnungen, Intentionen, Pläne, Einstellungen und Emotionen sowie Thema und Gegenstand des Gesprächs). Ausgehend davon, dass ein Verstehen des Diskurses die Bildung eines entsprechenden kohärenten mentalen Modells voraussetzt, untersucht die Autorin Nachfragen, die dazu dienen, Dinge klarzustellen und Missverständnisse zu vermeiden. Diese fungieren laut der Untersuchung als Mittel, die Kohärenz des gesprochenen Diskurses zu erhöhen. Die verschiedenen Typen von Missverständnissen, die Nachfragen auslösen, werden im Artikel nach mehreren Kriterien systematisiert: a) nach Etappen oder Ebenen der Diskursverarbeitung, wie sie in der Psycholinguistik unterschieden werden, so etwa Wortidentifikation, Wortschatz (unbekannte Wörter), (Mehrdeutigkeit der) Satzstruktur, Diskurs; b) nach Komponenten des Sprechakts hinsichtlich seiner Rezeption: Referenz, Prädikation, Bedeutung, illokutionäre Kraft, Gelingensbedingungen und implizite Information; c) nach Ebenen/Typen des mentalen Modells (der Kommunikationssituation): Oberflächenstruktur, propositionale Repräsentation und mentales Modell (inkl. Hintergrundwissen des Sprechers).

Stichwörter: Nachfrage, mentales Modell, Diskursverarbeitung, Diskursverständnis, Kohärenz, Missverständnis, Wissen, gesprochener Diskurs.

\section{Résumé in French}

L'article vise à élucider les caractéristiques cognitives et comunicatives des questionsécho dans le discours conversationnel anglais. La recherche a été réalisée sur la base des fragments du discours conversationnel avec les questions-écho, récupérés dans des films britanniques et américains. En développant l'idée des recherches discoursives de T. van Dijk faisant suite à sa théorie sociocognitive ainsi que le concept de l'analyse cognitive, l'article se propose en tant qu'une nouvelle approche à l'égard des questionsécho. Celles-ci étant interprétées, par conséquent, comme moyen de la formation ou de l'actualisation d'un modèle mental du contexte de la situation de communication qui met en valeur le processus de communication; ou comme modèle d'un événement au 
passé qui se définit en tant qu'élément important d'un modèle de contexte (c'est-à-dire des connaissances générales des interlocuteurs). Ainsi, les questions-écho s'utilisent afin de préciser les éléments d'un modèle mental qui sont d'une grande importance pour l'interlocuteur à un moment donné. Il s'agit de l'information sur l'identité de l'interlocuteur, son statut et son rôle, ses connaissances, ses convictions, ses attentes, ses émotions ou le thème de la conversation. Vu que la compréhension du discours sous-entend la création dэun modèle mental cohérent de celui-ci, l'article s'attache à exploiter les questions-écho, utilisées pour surmonter les cas de la communication en défaut en tant que moyen de l'intensification de la cohérence du discours conversationnel. Par conséquent, l'article se veut systématiser les types d'incompréhension, exigeant l'usage des questions-écho, en fonction du nombre de critères dont les niveaux de la perception du discours, déterminés par la psycholinguistique (l'identification du mot, le lexique [les unités lexicales inconnues], la structure syntaxique [équivoque], le discours); les éléments de l'acte de parole du point de vue de sa perception: les références, les prédications, le sens du mot, la force illocutoire, les conditions de réussite, les informations implicites; les niveaux/les types de modèle mental (de la situation de communication): la structure de surface, la base de texte/la représentation propositionnelle, le modèle mental qui comprend les connaissances de l'interlocuteur.

Mots-clés: la question-écho, le discours conversationnel, les connaissances, la cohérence, le modèle mental, l'incompréhension, la compréhension du discours.

\section{Résumé in Russian}

В статье рассматриваются когнитивно-коммуникативные характеристики вопросов-переспросов в англоязычном диалогическом дискурсе. Исследование проводилось на материале фрагментов диалогического дискурса, содержащих вопросы-переспросы, из британских и американских кинофильмов. Развивая положения социокогнитивной теории дискурсивных исследований Т. ван Дейка 
и когнитивный анализ дискурса, автор предлагает подход к рассмотрению вопросов-переспросов как средства построения/обновления ментальной модели контекста коммуникативной ситуации, которая постоянно контролирует общение, и модели ситуации события в прошлом, которое рассматривается как составляющая модели контекста (т.е. общие знания коммуникантов). Следовательно, вопросы-переспросы используются для уточнения компонентов ментальной модели, важных для говорящего в данный момент (таких как личность собеседника, его статус и роль, знания, убеждения, ожидания, интенции, планы, отношение, эмоции и предмет разговора). Руководствуясь положением о том, что понимание дискурса предполагает создание его когерентной ментальной модели, автор рассматривает вопросы-переспросы, используемые для преодоления коммуникативных сбоев, как средство увеличения когерентности диалогического дискурса. Типы непонимания, требующие использования вопросов-переспросов, систематизированы в работе в соответствии с рядом критериев: уровнями восприятия дискурса, выделяемыми в психолингвистике (идентификация слова, лексика (неизвестные лексические единицы), (неоднозначная) синтаксическая структура, дискурс); компонентами речевого акта с точки зрения его восприятия: референции, предикации, значения, иллокутивной силы, условий успешности и имплицитной информации; уровней/типов ментальной модели (коммуникативной ситуации): поверхностной структуры, текстовой базы/пропозициональной репрезентации и ментальной модели (включающей знания говорящего).

Ключевые слова: вопрос-переспрос, диалогический дискурс, знания, когерентность, ментальная модель, непонимание, понимание дискурса.

Article was received by the editorial board 15.04.17;

Reviewed 22.04.17. and 09.05.17.

Similarity Index 4\%. 